\title{
Helsesøster: Følger du de nye, nasjonale anbefalingene?
}

Nye retningslinjer angir hvordan skolehelsetjenesten for barn og unge skal være. En kartlegging viser stor variasjon i oppfølgingen av kravene.

\section{forfatter}

\section{Kristin Waldum-Grevbo}

Leder, Landsgruppen av helses østre NSF

\section{Nøkkelord}

Barn Ungdom Undervisning Skolehelsetjeneste Skole

Sykepleien 2018 106(70773)(e-70773)

DOI: https://doi.org/10.4220/Sykepleiens.2018.70773

\section{HOVEDBUDSKAP}

En elektronisk kartlegging, besvart av over halvparten av helsesøstrene i skolehelsetjenesten, viser at det er stor variasjon når det gjelder i hvilken grad skolehelsetjenesten følger anbefalingene i den nye nasjonale, faglige retningslinjen for skolehelsetjenesten. Respondentene nevner særlig fire årsaker til ulikhet i tilbudet: helsesøsters stillingsbrøk og tilgjengelighet i skolen, skolehelsetjenestens beliggenhet i skolebygget, ulikt lovverk i skole og helsetjeneste og hvor langt implementeringen av de nye retningslinjene har kommet $\mathrm{i}$ kommunene. 
I 2017 ble Nasjonale faglige retningslinjer for helsestasjons- og skolehelsetjenesten (1) lansert for første gang. Den erstatter veileder til forskrift av 3. april 2003 nr. 450 (2). Retningslinjen er utarbeidet for å tydeliggjør de faglige kravene til hvordan tjenesten for barn og unge 0-20 år skal eller må være. Den består også av anbefalinger om hvordan innholdet $\mathrm{i}$ tjenesten bør være for å oppnå god praksis og dermed også faglig forsvarlighet $\mathrm{i}$ hele landet.

\section{Om retningslinjen}

Retningslinjen er i fire deler: Fellesdel, helsestasjon, skolehelsetjenesten og helsestasjon for ungdom. I den innledende beskrivelsen av målet med retningslinjen for helsestasjons- og skolehelsetjenesten står det at retningslinjen skal gjøre myndighetenes krav til innholdet i tjenestene tydelig, og bidra til følgende:

- god kvalitet og forsvarlig drift

- helhetlige tilbud

- riktige prioriteringer

- mindre uønsket variasjon

- likeverdige tilbud

- å styrke mestring blant foreldre, barn og ungdom

Retningslinjer er faglig normerende, noe som betyr at de beskriver anbefalt praksis. Hvis virksomheten velger en praksis som fraviker fra nasjonale faglige retningslinjer skal det, ifølge pasientjournalforskriften $\S 8$ bokstav h, dokumenteres hvorfor annen praksis er valgt. Det viktige med at skolehelsetjenesten samhandler med skolen er tydeliggjort i retningslinjen for skolehelsetjenesten (3).

\section{Stor variasjon i tilbudet}


En kartlegging utført av leder av Landsgruppen av helsesøstre, Norsk Sykepleierforbund (LaH NSF) i desember 2017, viser at det er stor variasjon når det gjelder i hvilken grad helsesøstrene i skolehelsetjenesten følger anbefalingene i den nye nasjonale retningslinjen for skolehelsetjenesten (3).

Respondentene - helsesøstre og som jobber i skolehelsetjenesten - oppgir fire hovedgrunner til dette:

- ulik tilgjengelighet i tjenesten fordi helsesøsters stilling på skolen varierer

- skolehelsetjenestens beliggenhet på skolen som fremmer eller hemmer samarbeid. Noen helses $\varnothing$ stre har kontor i nærheten av samarbeidspartnere. Andre har kontor langt unna ledelsen på skolen

- lovverket fører til at det ofte er type «bestillerutfører» fordeling mellom skolen og skolehelsetjenesten fordi det er opp til skolen å vurdere i hvilken grad de ønsker skolehelsetjenestens bidrag i undervisning og grupper

- retningslinjen er ny og i varierende grad implementert i kommunen

\section{Metode}

For å kartlegge i hvilken grad helsesøstre i skolehelsetjenesten i norske kommuner følger retningslinjen for skolehelsetjenesten (3), ble en elektronisk spørreundersøkelse sendt ut til 3750 medlemmer i LaH NSF i desember 2017. Kun medlemmer av LaH NSF, som jobber i skolehelsetjenesten, ble bedt om å svare. Undersøkelsen er basert på de konkrete anbefalingene for arbeidet i skolehelsetjenesten.

Et eksempel på hvordan en anbefaling ble utformet som en påstand respondentene kunne svare «ja» eller «nei» på var som følger: 
Anbefaling: «Undervisning: Skolehelsetjenesten skal bidra i undervisning i grupper eller klasser i den utstrekning skolen ønsker det.» Påstanden ble: «Skolehelsetjenesten har planlagt å bistå skolen med undervisning og/eller grupper dette skoleåret?»

Det var mulig å kommentere og utdype i fritekst under hver påstand.

\section{三 «Totalt har helsesøsterårsverkene økt med 134 fra 2016 til 2017.»}

Ifølge den siste nasjonale kartleggingen fra Helsedirektoratet av hvor i tjenesten de ulike fagpersonene jobber, var det i 2016 totalt 1322 helsesøsterårsverk i skolehelsetjenesten fordelt på barneskole, ungdomsskolen og videregående skole (4). Totalt for hele helsestasjons- og skolehelsetjenesten har helsesøsterårsverkene økt med 134 fra 2016 til 2017 (5). Det finnes ingen statistikk på hvor i tjenesten økningen har vært, så vi vet ikke hvor mange flere stillinger det er blitt i barne-, ungdoms- eller videregående skole det siste året.

Det var 679 respondenter som besvarte undersøkelsen. Det tilsvarer rundt 51 prosent av helsesøstrene i skolehelsetjenesten, hvis vi sammenligner med de siste tallene vi har fra 2016, der helsesøstre i skolehelsetjenesten er skilt ut fra dem som jobber andre steder (3).

\section{Resultater}


Hoveddelen av respondentene svarer at de har faste samarbeidsmøter med skolens ledelse slik det er anbefalt i retningslinjen (3) (figur 1). Fritekstsvarene viser at det er stor variasjon når det gjelder hyppighet og hvem som deltar på møtene. Det varierer fra faste ukentlige møter til årlige møter. Noen steder har helsesøster bare faste møter med rektor alene. På andre skoler er møtene ikke med rektor, men med rådgiver, sosiallærer, psykologisk-pedagogisk tjeneste (PPT), fysioterapeut eller barnevernstjenesten.

Andre anbefalinger gjelder helsesøstrers deltakelse på skolens planleggingsdager og foreldremøter, samt samarbeid med elevrådet (3).

Bare 30 prosent av helsesøstrene svarer at de deltar på skolenes planleggingsdager. De utfyllende kommentarene i undersøkelsen tyder på at det er stor forskjell på om helsesøster blir invitert inn, eller om hun/han inviterer seg selv inn.

\section{«Det er i videregående skole det er minst vanlig at helsesøstrene deltar på foreldremøtene.»}

Så liten andel som 18 prosent av helsesøstrene hadde fast samarbeid med elevrådet da undersøkelsen ble gjennomført. Den tydelige anbefalingen i retningslinjen om å ha slikt samarbeid har likevel ført til at flere har lagt planer om møter med elevrådet. Flere respondenter svarer noe lignende som denne helsesøsteren:

«Jeg har ikke hatt slik samarbeid før, men jeg har planlagt første møte 18. januar.»

Det å møte foreldrene på foreldremøter er utbredt, særlig det første året på barne-, ungdoms- og videregående skole. 
65 prosent av helsesøstrene deltar på foreldremøte i 1 . klasse på barneskolen, 69 prosent deltar i 8. klasse og 56 prosent er med på møtene i 1. videregående skole. Det er også relativt vanlig å delta på andre klassetrinn i barneskolen. Det er i videregående skole det er minst vanlig at helsesøstrene deltar på foreldremøtene. 44 prosent av respondentene sier at de ikke har planlagt å delta på et eneste foreldremøte dette skoleåret (6).

Figur 1. Skolehelsetjenesten har faste møter med ledelsen på skolen

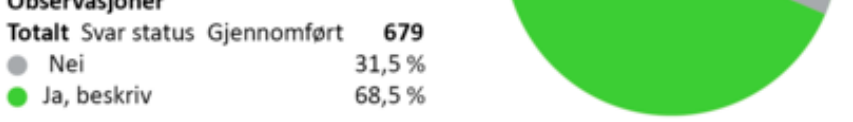

\section{Bidrar i undervisning og grupper}

I de nye nasjonale retningslinjene står det at skolehelsetjenesten skal bidra i undervisning i grupper eller klasser i den grad skolen ønsker det (3). Dette blir klargjort, som følgende, i retningslinjen hva det forventes at helsesøster bidrar med:

- bistand $\mathrm{i}$ undervisningen om temaer i skolens læreplaner og undervisning knyttet til spesielle utfordringer ved skolen eller nærmiljøet

- Samtaler, helseopplysning og veiledning i grupper til elever med særskilte behov (1)

Hele 96 prosent av dem som har besvart undersøkelsen har planer om å undervise i løpet av skoleåret, men temaene varierer (figur 2). Det er mest vanlig å ha undervisning innen temaet seksuell og psykisk helse. Ved omkring halvparten av skolene tilbyr man grupper for barn som har opplevd samlivsbrudd. 

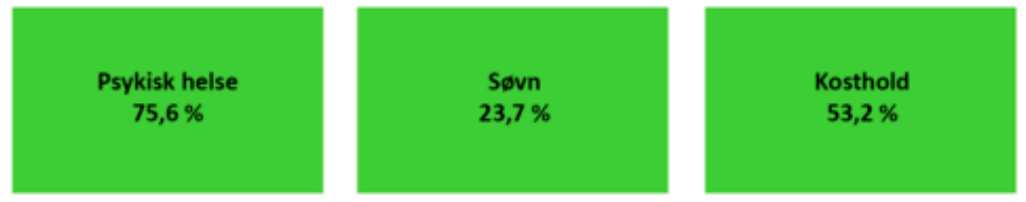

Pubertet, kropp, seksuell helse $92,8 \%$
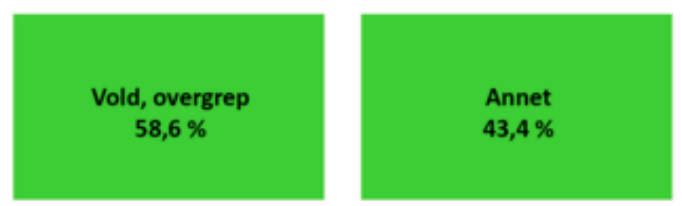

\section{Universelle tiltak for alle elever}

Kartleggingen viser at det er stor variasjon når det gjelder hvilke universelle tiltak (faktaboks) skolehelsetjenesten og skolen samarbeider om (figur 3). Det er mindre vanlig å samarbeide om tiltak som gjelder fysisk aktivitet og skolemåltid, enn tiltak for et godt psykososialt skolemiljø.

\section{UNIVERSELLE TILTAK}

Befolkningsrettet (universell) forebygging er tiltak rettet mot folk flest eller mot hele befolkningsgrupper uten at en har identifisert individer eller grupper med forhøyet risiko. Tiltakene som gjennomføres kan i prinsippet komme alle i den aktuelle befolkningen eller befolkningsgruppen til gode. Befolkningsrettede tiltak har gjerne små effekter på den enkelte, men siden tiltakene når mange mennesker, er effekten gjerne stor for samfunnet.

Grupperettet (selektiv) forebygging er tiltak som rettes mot grupper med kjent og forhøyet risiko for å utvikle sykdom. Risiko kan vurderes på grunnlag av både miljøbaserte og individbaserte helsedeterminanter. Grupperettede tiltak kan ha god effekt på den enkelte og gruppen, men noe mindre effekt for forekomsten i hele samfunnet, avhengig av hvor store risikogruppene er. 
Individrettet (indikativ) forebygging er tiltak rettet mot individer med høy sykdomsrisiko eller høyt symptomnivå. Eksempelvis kan dette være individer som har symptomer på depresjon eller andre lidelser, men som ikke møter kriteriene for en mer alvorlig diagnose. Individrettet forebygging er nært beslektet med begrepet sekundærforebygging. Individrettede tiltak har i mange tilfeller svært god effekt for den enkelte, men er av mindre betydning for folkehelsen siden det kun er dem som har høy risiko eller er i ferd med å bli syke som får tiltaket.

(6)

Strukturen på tiltakene varierer fra at det er en rød tråd gjennom kommunale planer og handlingsplaner på skolen, til at tiltak settes i verk ad hoc og individuelt for den enkelte elev som har behov for koordinert hjelp fra skole og skolehelsetjenesten. Dette gjelder også på viktige samarbeidstemaer som mobbing og frafall i skolen som er spesielt vektlagt i retningslinjen for skolehelsetjenesten (3) (figur 4).

Figur 3. Samarbeid om tiltak
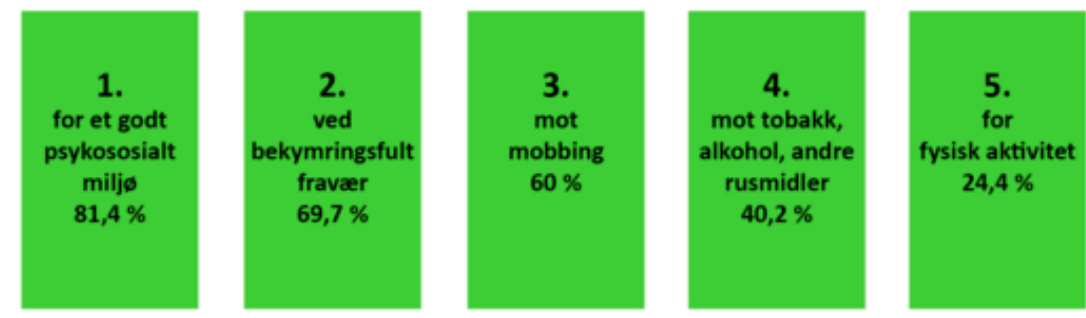

Figur 4. På hvilken måte samarbeides det om tiltak
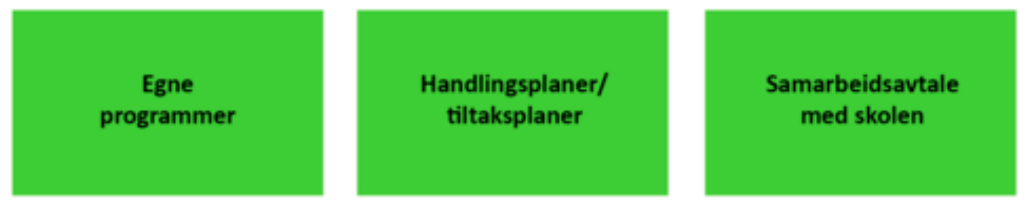

Team
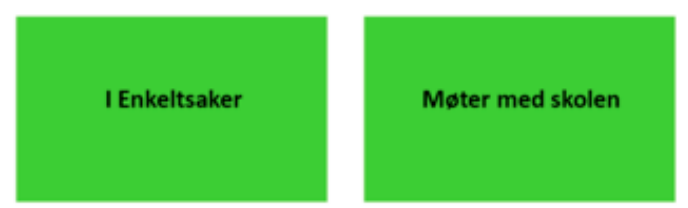

\section{Individuelle konsultasjoner}


Retningslinjene anbefaler individuelle konsultasjoner med alle elever i 1. klasse på barneskolen og i 8. klasse. Det er anbefalt at 1. klasseundersøkelsen foregår på skolen og at både helsesøster og lege deltar. Dette gjennomføres i liten grad i dag (figur 5). 8. klassesamtale anbefales utført av helsesøster med alle elever. Resultatene viser at samtalene i 8. klasse er en prioritert oppgave i ungdomsskolen. 80 prosent av helsesøstrene oppgir at de gjennomfører denne samtalen.

Figur 5. Skolehelsetjenesten gjennomfører skolestartsundersøkelse på skolen

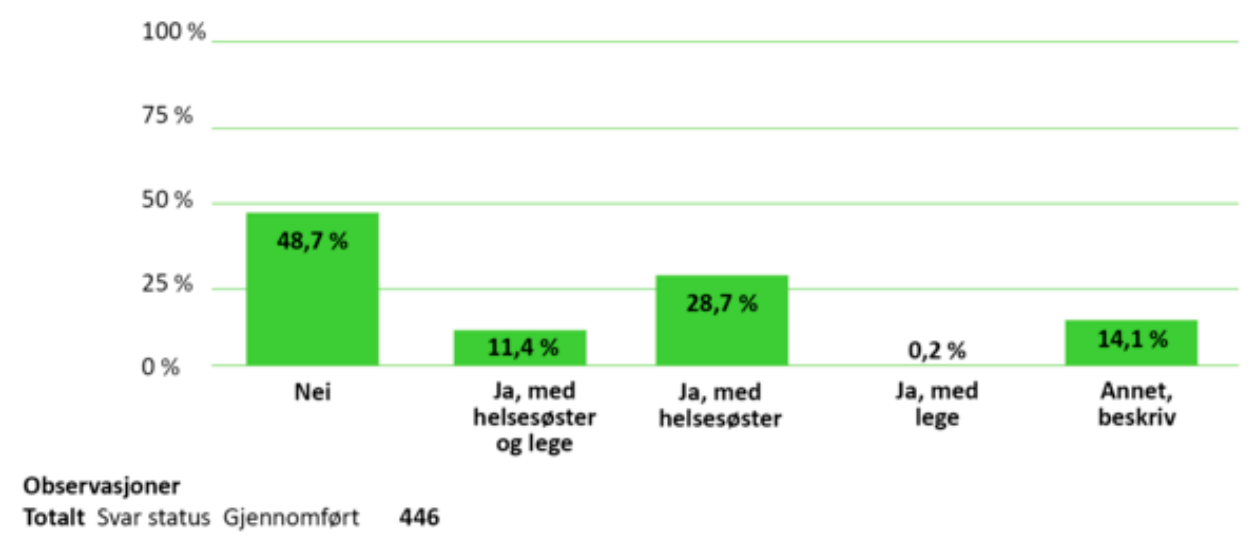

\section{Ulikhet i samarbeid og tilbud}

Strukturert samarbeid med skolen i form av felles møter og planer er særlig vektlagt i de nye retningslinjene. Helsesøstrene som har svart på undersøkelsen beskriver samarbeidet som varierende fra skole til skole og fra kommune til kommune både når det gjelder omfang og innhold.

Følgende type sitat går igjen i kommentarene fra respondentene og sammenfatter funnene $\mathrm{i}$ undersøkelsen på en god måte:

«Samarbeidet er Ikke satt i system, og varierer mellom de ulike skolene og de ulike helsesøstrene.»

Samtidig er det andre helsesøstre som beskriver at de har et godt samarbeid: 
«Helsesøster samarbeider godt med skolens ledelse, og de blir hørt og får gjennomslag for innspill.

Helsesøster er med som en del av Elevtjenesten sammen med rådgivere, PPT og ungdomsveileder.»

\section{Tilstedeværelse}

Betydningen av at helsesøster er mer til stede på skolen enn før, på grunn av økte ressurser til skolehelsetjenesten, trekkes frem av mange respondenter. Det er flere helsesøstre som kommenterer at den nasjonale satsingen på skolehelsetjenesten har hatt positiv effekt:

«Jeg har et godt samarbeid med skolen «min». Det er blitt betydelig mye bedre nå etter at jeg har økt min tilstedeværelse på skolen etter at vi har mottatt midler fra Helsedirektoratet for å styrke skolehelsetjenesten. Med økt tilstedeværelse vil også helsesøster bli sett på som en ressurs og bli en del av skolen.»

«Vi har hatt svært lite ressurser ut i skolehelsetjeneste, spesielt i barneskolen. Ressursene er styrka frå hausten 2017. Det systematiske samarbeidet er ikkje skikkeleg på plass, men er i ferd med å bli etablert.»

\section{三 «Skolehelsetjenesten er lengst unna anbefalte normtall.»}

«Det er et stort forbedringspotensial, men utvikling ser

veldig positiv ut fordi vi har fått litt økte ressurser i

skolehelsetjenesten.» 
De siste årsverkskartleggingene fra 2015 og 2016 (4,

6) viser at skolehelsetjenesten er lengst unna anbefalte normtall (8) (faktaboks) i barneskolen og at variasjonen mellom kommuner og fylker når det gjelder tilstedeværelse er stor. Helsesøsterårsverkene i helsestasjons- og skolehelsetjenesten har økt med 252 årsverk totalt siden 2015. Det finnes ikke oversikt over hvor helsesøstrene jobber. De anbefalte normtallene ble utarbeidet i 2010 (7) og er ikke justert i tråd med oppgavene i dagens nye retningslinjer.

\section{SKOLEHELSETJENESTEN}

En helsesøster i 100 prosent stilling kan følge opp, maksimalt, en av følgende kategorier:

- 300 elever i barneskolen

- 550 elever i ungdomsskolen

- 800 elever i videregående skole

(6)

I følge en kartlegging fra 2017, utført av LaH NSFs utdanningsutvalg, utdannes det for få helsesøstre til å møte behovet for helsesøstre i helsestasjons- og skolehelsetjenesten fremover (9).

\section{Skolehelsetjenestens beliggenhet}

I flere av kommentarene fra respondentene, er skolehelsetjenestens lokaler et tema. Flere gir tilbakemelding om at skolehelsetjenestens beliggenhet på skolen er til hinder for samarbeid:

«Samarbeidet begrenses av at skolehelsetjenestens kontor er plassert i en annen del av skolebygget enn ledelsen.»

«Jeg tenker også det er viktig å jobbe for å få kontor i nærheten av administrasjonen til skolen. Jeg sitter helt alene på et kontor i en egen bygning.»

En annen helsesøster gir følgende tilbakemelding: 
«Vi er samlokalisert, og samarbeider hver dag rundt enkeltelever og på systemnivå.»

\section{Bestiller og utfører}

Det at skolen ikke er like forpliktet til å samarbeide gjennom lovverket på samme måte som skolehelsetjenesten, opplever helsesøstrene som både provoserende og til hinder for godt samarbeid.

Mange reagerer på ordlyden i forskrift om kommunens helsefremmende og forebyggende arbeid $\mathrm{i}$ helsestasjons- og skolehelsetjenesten § 2-3 (10) som sier at helsestasjons- og skolehelsetjenestens tilbud til barn og ungdom 0-20 år skal omfatte: «bistand og undervisning i gruppe/klasse/foreldremøter i den utstrekning skolen ønsker det». Ulike helsesøstre beskriver det slik:

«Jeg opplever det veldig varierende fra skole til skole, hvor mye de ønsker å bruke vår kompetanse inn i systemarbeid, skolemiljø, fysisk aktivitet og de andre viktige emnene som handler om elevers fysiske og psykososiale helse. Det er for mye opp til skolen å bestemme det, tenker jeg.»

\section{三 «Det ble foreslått en endring $i$ opplæringsloven som gir skolen plikt til flerfaglig samarbeid.»}

«Jeg synes det er betenkelig at det ikke er retningslinjer for skolen i forhold til samarbeid med skolehelsetjenesten. Det er hele tiden opp til den enkelte skole og den enkelte lærer hvor interessert de er i samarbeid.»

«Det er viktig at helsesøster er litt «på» og er synlig både overfor elever og ansatte, slik at skolehelsetjenesten blir en del av skolen.» 
«Det har stort sett vært helsesøster som har initiert samarbeid med skolen. Når det er svart nei på en del av spørsmålene, er det fordi jeg ikke har kommet i posisjon på skolen. Det er stor ulikhet mellom skolene på om de ser helsesøster som ressurs, og hvordan de inviterer helsesøster inn i skolen og samarbeid.»

I Prop. 52 L (2017-2018), fra regjeringen, ble det foreslått en endring i opplæringsloven som gir skolen plikt til flerfaglig samarbeid (11). Lovendringen ble nylig vedtatt av Stortinget, men er ennå ikke trått i kraft.

\section{Implementering}

Kartleggingen ble sendt ut kort tid etter at retningslinjen ble lansert, og den sier derfor lite om i hvilken grad retningslinjen på sikt vil bidra til at praksis endres i tråd med målet. Målet er en mindre variasjon i tjenesten og et mer likeverdig tilbud i helsestasjons- og skolehelsetjenesten (3).

I flere fritekstsvar beskriver likevel helsesøstre at de allerede er i ferd med å endre praksis på bakgrunn av anbefalingene. Noen har også nevnt at det å måtte svare på en slik kartlegging i seg selv var bevisstgjørende.

\section{Veien videre}

Flere av helsesøstrene i undersøkelsen har kommentert at de nye faglige retningslinjene har påvirket deres utøvelse av helsesøsterfaget (3). Siden undersøkelsen ble sendt ut før kommunene har rukket å implementere de nye retningslinjene, er det grunn til å tro at de på sikt vil føre til en endring av praksis flere steder. Helsedirektoratet har blant annet hatt flere fylkesvise implementeringskonferanser i samarbeid med fylkesmennene i etterkant av at denne kartleggingen ble sendt ut. Det vil derfor være interessant å følge opp med en tilsvarende kartlegging om en stund for å se om det skjer en endring av praksis over tid. 


\section{«Det pågår en randomisert, kontrollert studie i 15 norske kommuner.»}

Det pågår en randomisert, kontrollert studie i 15 norske kommuner som heter «Et lag rundt eleven» (12). Studien skal se på hvordan økt helsesøsterressurs påvirker samarbeidet mellom skolehelsetjenesten, lærere, skoleledere og sosialpedagogisk personale og om dette kan bidra til å styrke elevenes læringsmiljø. Prosjektet gjennomføres av Nordisk institutt for studier av innovasjon, forskning og utdanning (NIFU) i samarbeid med Læringsmiljøsenteret ved Universitetet i Stavanger og Folkehelseinstituttet. Prosjektet er finansiert av Utdanningsdirektoratet.

Et annet forskningsprosjekt er «Skolehelse.no». I dette prosjektet er det utarbeidet et elektronisk spørreskjema for elever i 8. klasse. Informasjonen fra spørreskjema skal både brukes for å planlegge en 8. klassesamtale helsesøster utfører med den enkelte elev og som statistikk på gruppenivå tsom kan tas inn i samarbeidet med skolen. Begge deler er vektlagt i de nye retningslinjene (3). Pilotfasen av prosjektet er akkurat avsluttet og det foreligger ikke noen oppsummering å referere til enda. Prosjektet er forankret i Regionalsenteret for barn og unges psykiske helse, avdeling øst og sør. Både Helsedirektoratet, ehelsedirektoratet og LaH NSF er involvert i prosjektet.

Det er ellers lite forskning som ser på den direkte effekten av skolehelsetjenestens arbeid.

\section{Referanser}

1. Helsedirektoratet. Nasjonal faglig retningslinje for det helsefremmende og forebyggende arbeidet $\mathrm{i}$ helsestasjon, skolehelsetjeneste og helsestasjon for ungdom. Oslo: Helsedirektoratet; 2018. Tilgjengelig fra:

https://helsedirektoratet.no/retningslinjer/helsestasjonsog-skolehelsetjenesten (nedlastet 30.03.2018). 
2. Sosial- og helsedirektoratet. Helsefremmende og forebyggende arbeid i helsestasjons- og skolehelsetjenesten Veileder til forskrift av 3. april 2003 nr. 450. Oslo: Sosial- og helsedirektoratet; 2004. IS- 1154.

3. Helse- og omsorgsdepartementet. Forskrift om pasientjournal [internett]. Oslo: Helse- og omsorgsdepartementet; 2001. [oppdatert: 01.01.2018]. Tilgjengelig fra: https://lovdata.no/dokument/SF/forskrift/2000-1221-1385 (nedlastet 30.04.2018).

4. Helsedirektoratet. Kartlegging av årsverk i helsestasjons- og skolehelsetjenesten. Oslo: Helsedirektoratet; 2016. IS-2543. Tilgjengelig fra: https://helsedirektoratet.no/publikasjoner/kartleggingav-arsverk-i-helsestasjons-og-skolehelsetjenesten (nedlastet 30.04.2018).

5. Statistisk sentralbyrå. Kommunehelse grunnlagsdata (K) 1999 - 2017 15. mars 2018. Tilgjengelig fra: https://www.ssb.no/statbank/table/04685/? rxid=056c713a-6c0e-4667-84c0-a75689f43df2 (nedlastet 09.05.2018).

6. Waldum-Grevbo KS, Haugland T. En kartlegging av helsesøsterbemanningen i skolehelsetjenesten. Sykepleien Forskning 2015;10(4):352-60. Tilgjengelig fra: https://sykepleien.no/forskning/2015/11/enkartlegging-av-helsesosterbemanningen-iskolehelsetjenesten (nedlastet 30.04.2018).

7. Major EF, Dalgard OS, Mathisen KS, Nord E, Ose S, Rognerud M, Aarø LE. Rapport 2011:1. Bedre føre var- Psykisk helse: Helsefremmende og forebyggende tiltak og anbefalinger. Oslo: Folkehelseinstituttet; 2011. Tilgjengelig fra: https://www.fhi.no/publ/2011/bedre-fore-var-psykiskhelse-hels/ (nedlastet 08.05.2018). 
8. Helsedirektoratet. Utviklingsstrategi for

helsestasjons- og skolehelsetjenesten. Oslo:

Helsedirektoratet; 2010. IS-1798. Tilgjengelig fra:

https://helsedirektoratet.no/publikasjoner/utviklingsstrategi-

for-helsestasjons-og-skolehelsetjenesten (nedlastet 30.04.2018).

9. Landsgruppen av helsesøstre NSF.

Helsesøsterstillinger og utdanning av helsesøstre. En kartlegging av behov for helsesøsterstillinger og helsesøsterutdanning. Rapport nr. 2. Oslo:

Utdanningsutvalget LaH NSF; 2017. Tilgjengelig fra: https://www.nsf.no/vis-artikkel/3545775/10501/Detutdannes-for-faa-helsesostre (nedlastet 30.04.2018).

10. Helse- og omsorgsdepartementet. Forskrift om kommunens helsefremmende og forebyggende arbeid i helsestasjons- og skolehelsetjenesten. Oslo: Helse- og omsorgsdepartementet; 2013. Tilgjengelig fra: https://lovdata.no/dokument/SF/forskrift/2003-04-03$\underline{450}$ (nedlastet 30.04.2018).

11. Prop. 52 L (2017-2018) Endringar i opplæringslova, friskolelova og folkehøgskolelova (plikt til å tilby intensiv opplæring og plikt til fleirfagleg samarbeid m.m.) Oslo: Regjeringen; 2018. Tilgjengelig fra:

https://www.regjeringen.no/no/dokumenter/prop.-52-l20172018/id2594304/ (nedlastet 28.05.18).

12. Et lag rundt eleven [Internett]. Oslo: NIFU Nordisk institutt for studier av innovasjon, forskning og utdanning; [sitert: 30.04.2018]. Tilgjengelig fra: https://www.lagrundteleven.no/ (nedlastet 30.05.18). 